\title{
Peptides targeting the mitogen-activated protein kinase pathway (JNK/Jun) fail to reduce infarct volume after permanent MCAO in Sprague Dawley rats
}

\author{
Cindy $\mathrm{Si}^{1}$, Kym Campbell ${ }^{1}$, Jane L. Cross ${ }^{1}$, Paul M. Watt ${ }^{2}$, Nadia Milech ${ }^{2}$, Neville W. Knuckey ${ }^{1}$ and Bruno \\ P. Meloni ${ }^{1 *}$ \\ ${ }^{1}$ Centre for Neuromuscular and Neurological Disorders/University of Western Australia, Australian Neuro-muscular Research \\ Institute and Department of Neurosurgery, Sir Charles Gairdner Hospital, Western Australia, Australia; \\ ${ }^{2}$ Phylogica Ltd and Telethon Institute for Child Health Research, University of Western Australia, Western Australia,
} Australia

\begin{abstract}
In this study we have assessed the ability of two TAT-fused peptides PYC36D-TAT and JNKI-1D-TAT (JNKI-1 or XG-102), which respectively inhibit jun proto-oncogene (c-Jun) and c-Jun N-terminal kinase (JNK) activation, to reduce infarct volume and improve functional outcome (adhesive tape removal) following permanent focal cerebral ischemia/pMCAO in Sprague Dawley rats. In addition, PYC36L-TAT fused to an ischemic brain homing peptide (HP-PYC36L-TAT) was also assessed. Prior to animal experiments all PYC36D-TAT, JNKI-1DTAT and HP-PYC36L-TAT peptide batches were tested in vitro and protected cortical neurons against glutamate excitotoxicity. Rats were treated intravenously in two separate trials. Trial 1 used high peptide doses (PYC36D-TAT: 500, 1000 or $1500 \mathrm{nmol} / \mathrm{kg}$; JNKI-1D-TAT: 500, 1000 or $1500 \mathrm{nmol} / \mathrm{kg}$; PYC36Dscrambled-TAT: $1120 \mathrm{nmol} / \mathrm{kg}$ ) administered 1 hour after MCAO. Trial 2 used lower doses (PYC36D-TAT: 50 or $250 \mathrm{nmol} / \mathrm{kg}$; HP-PYC36L-TAT: $250 \mathrm{nmol} / \mathrm{kg}$; JNKI-1D-TAT: $250 \mathrm{nmol} / \mathrm{kg}$; D-TAT: $250 \mathrm{nmol} / \mathrm{kg}$ ) administered 2 hours after MCAO. Contrary to other stroke animal studies, but in line with our previous findings, no treatment significantly reduced infarct volume or improved functional score measurements compared to vehicle (saline) treated animals when assessed 24 hours post-MCAO.
\end{abstract}

Key words: JNK, c-Jun, JNKI-1D-TAT, PYC36D-TAT, pMCAO, focal cerebral ischemia, homing peptide, Sprague Dawley rats

\section{Introduction}

Currently, the only therapeutic treatment for ischemic stroke is thrombolysis using tissue plasminogen activator (tPA), which must be administered within 4.5 hours and is associated with a $7 \%$ risk of intracerebral haemorrhage (Donnan and Davis, 2005). In addition, it is estimated that tPA therapy is only administered to $5-15 \%$ of ischemic stroke patients admitted to hospital. Therefore there is an urgent need to identify and assess new potential neuroprotective targets/therapies for future clinical application to reduce ischemic brain injury and improve stroke patient outcomes.

One cell death pathway that has recently been targeted following cerebral ischemia is the mitogenactivated protein kinase (MAPK) pathway, with most attention being focused on the blockade of the c-Jun $\mathrm{N}$-terminal kinase (JNK) protein (Borsello et al, 2003; Wiegler et al, 2008; Vaslin et al, 2011). JNK is able to phosphorylate proteins involved in cell death including p53 and Bcl-2 family members Bad, Bax, Bid and Bim (Cao et al, 2002; Plesnila et al, 2001; Tsuruta et al, 2004; Wang et al, 2007). More recently, the activator protein-1 (AP-1) complex, namely the cJun protein, which is downstream of JNK, has also been targeted (Meade et al, 2010ab; Craig et al, 2011). The AP-1 complex is comprised of homodimerized c-Jun protein (or heterodimerized with other AP1 proteins; c-fos), which is activated following phosphorylation by JNK, promoting the expression of pro- cell death proteins such as Fas, Fas-L, DP5, Bax and c-Jun itself (Besirli et al, 2005; Gao et al, 2005). With respect to repressing the activity of JNK and c-Jun, recent strategies have used peptide inhibitors fused to the 11 amino acid cell penetrating peptide TAT. The two best characterized peptides are JNKI-1D-TAT (also known as JNKI-1 or XG-102), which inhibits JNK (Borsello et al, 2004; Table 1) and the PYC36D-TAT peptide that targets CJun (Meade et al, 2010ab; Craig et al, 2011).

However, despite the attractiveness of both JNK and c-Jun as therapeutic neuroprotective targets and positive JNKI-1D-TAT animal cerebral ischemia trials, a previous study in our laboratory using a transient focal ischemia stroke rat model did not reveal any significant reduction in infarct volume or functional improvement with either PYC36D-TAT or JNKI-1DTAT. Therefore, in the present study, we aimed to assess the PYC36D-TAT and JNKI-1D-TAT peptides in a permanent focal ischemia stroke model in a high and low dose trial. In addition, in one trial we also

${ }^{*}$ Correspondence should be sent to:

Bruno Meloni; Australian Neuro-muscular Research Institute; A Block, $4^{\text {th }}$ floor, QEII Medical Centre, Nedlands, Western Australia, 6009, Australia; Tel: +61 89346 3535; Fax: +61 89346 3487; Email: bruno.meloni@anri.uwa.edu.au 
evaluated the PYC36L-D-TAT peptide fused to a cerebral ischemia homing peptide reported (Hong et al, 2008) to aid delivery into the brain.

\section{Materials and Methods}

2.1. Rat permanent middle cerebral artery occlusion (MCAO) focal ischemia model

This study was approved by the Animal Ethics Committee of the University of Western Australia and all procedures were performed according to the guidelines established for the use of animals in experimental research as outlined by the Australian National Health and Medical Research Council. Male Sprague Dawley rats weighing 270 to $360 \mathrm{~g}$ were kept under controlled housing conditions with 12 hours light-dark cycle and had free access to food and water. Experimental animals were fasted from food overnight before permanent MCAO was performed.

\subsection{Induction of middle cerebral artery occlusion}

Anaesthesia was induced via a facemask with $4 \%$ isoflurane and maintained between 1.75 - 2.5\% isoflurane with a 2:1 combination of nitrous oxide and oxygen. Cerebral blood flow was monitored continuously with laser Doppler flowmetry (Blood Flow-Meter, AD Instruments, Sydney, NSW, Australia). The laser Doppler flow-probe was positioned $1 \mathrm{~mm}$ posterior to the bregma and $5 \mathrm{~mm}$ lateral to the midline of the right hemisphere. For trial 2 animals a cannula was inserted into the right femoral artery for continuous blood pressure monitoring and to provide samples for blood glucose and blood gas readings. Blood glucose was measured using a glucometer (MediSense Products, Abbott Laboratories, Bedford, MA, USA) and blood gases were measured using a blood gas analyser (ABL5, Radiometer Copenhagen, Copenhagen, Denmark). Blood pressure was maintained at 80 $100 \mathrm{~mm} \mathrm{Hg}$. Rectal temperature was measured by a rectal probe (Physitemp Instruments, Clifton, NJ, USA) and maintained at $37.0 \pm 0.5^{\circ} \mathrm{C}$ using a heating fan where necessary.

Permanent focal cerebral ischemia was induced using the intraluminal thread technique. The right common carotid artery (CCA) was exposed via a ventral neck incision. The external carotid artery (ECA) was isolated after cauterisation of the superior thyroid and occipital arteries. The isolated section of the ECA was ligated and cauterised to create a stump. The carotid body was removed and the pterygopalatine artery was ligated. A nylon thread (Trial 1: 5-0 monofilament with a $0.4 \mathrm{~mm}$ diameter silicone tip coated with polylysine; custom made. Trial 2: 4-0 nylon monofilament with a $0.39 \mathrm{~mm}$ diameter silicone tip; Doccol, Redlands, CA, USA) was inserted through the ECA stump into the CCA and advanced rostrally into the internal carotid artery (ICA) until the laser Doppler flowmetry recorded a $>25 \%$ decrease from baseline of cerebral blood flow. The monofilament was secured in two places (at the base of the ECA stump and on the ICA) for the rest of the experiment. In trial 1 all animals were given subcutaneous bupivacaine $(1.5 \mathrm{mg} / \mathrm{kg}$, all skin wounds except ventral neck), while in trial 2 all animals received bupivacaine and an intramuscular pethidine $(3 \mathrm{mg} / \mathrm{kg})$. Following surgery animals were placed in a clean cage where they had free access to food and water and housed in a holding room maintained at $25^{\circ} \mathrm{C}$.

In trial 1, prior to surgery and 24 hours after MCAO animals were assessed using a 5 point neurological scale, and any animal that showed no alteration in score was considered an experimental failure and withdrawn from the study.

\subsection{Post-surgical temperature monitoring}

Trial 1. Animal's rectal temperature was monitored and maintained between $37.0-38.0^{\circ} \mathrm{C}$ by cooling (cool room + fan) or warming (heat pad or fan heater) for a period of 2 hours post-surgery as required.

Trial 2. A radio transmitting temperature probe was inserted into the abdominal cavity for postoperative telemetric thermoregulation (LabVIEW 2010 version 10.0, National Instruments, Australia) as described previously (Zhu et al, 2005). Animals were allowed to recover in a climate-controlled chamber and their core body temperature maintained at normothermia $\left(37.0 \pm 0.2^{\circ} \mathrm{C}\right)$ by a cooling/heating fan when required.

\subsection{Peptides used in trials}

The PYC36D-TAT and JNKI-1D-TAT peptides were fused to the TAT cell penetrating peptide (HIV-1 $\left.\operatorname{TAT}_{(48-57)}\right)$ and synthesized in the protease-resistant D-retro-inverso form. Peptide sequences were as follows: PYC36D-TAT; H-PKISQYGQRRRGQLGG RRRQRRKKRG-NH2 and JNKI-1D-TAT; $\mathrm{H}$ TDQSRPVQPFLNLTTPRKPRPP-RRRQRRKKRG-

$\mathrm{NH} 2$ (underlined single letter code indicates $D$ isoform of the amino acid. TAT transduction domain is indicated by bold lettering). The D-retro-inverso form of the TAT peptide (D-TAT; HGRRRQRRKKRG-NH2) and a scrambled version of the PYC36 peptide (PYC36Dscrambled-TAT; $\mathrm{H}$ KRRGGILRYGQPQSQGRRRQRRKKRG-NH2) were also synthesized and used as controls. The HPPYC36L-TAT peptide was synthesized in the L-form and consisted of the PYC36 and TAT peptides in addition to a brain homing peptide sequence (Hong et al, 2008); H-GRKKRRQRRRGLQGRRRQGYQSIKP CLEVSRKNC-NH2. All peptides were synthesized and high-performance liquid chromatography purified 
by Mimotopes Pty Ltd (Melbourne, VIC, Australia). Peptides were prepared in normal saline in $300 \mu \mathrm{l}$ or $500 \mu \mathrm{l}$ volumes for intravenous administration and stored at $-80^{\circ} \mathrm{C}$ before use.

While we have previously shown that the PYC36DTAT and JNKI-1D-TAT peptides are neuroprotective using an in vitro glutamate excitotoxicity model (Meade et al, 2010a), we also confirmed that the HPPYC36L-TAT is neuroprotective in this model (Fig. 1; IC50: $1.5 \mu \mathrm{M}$ )

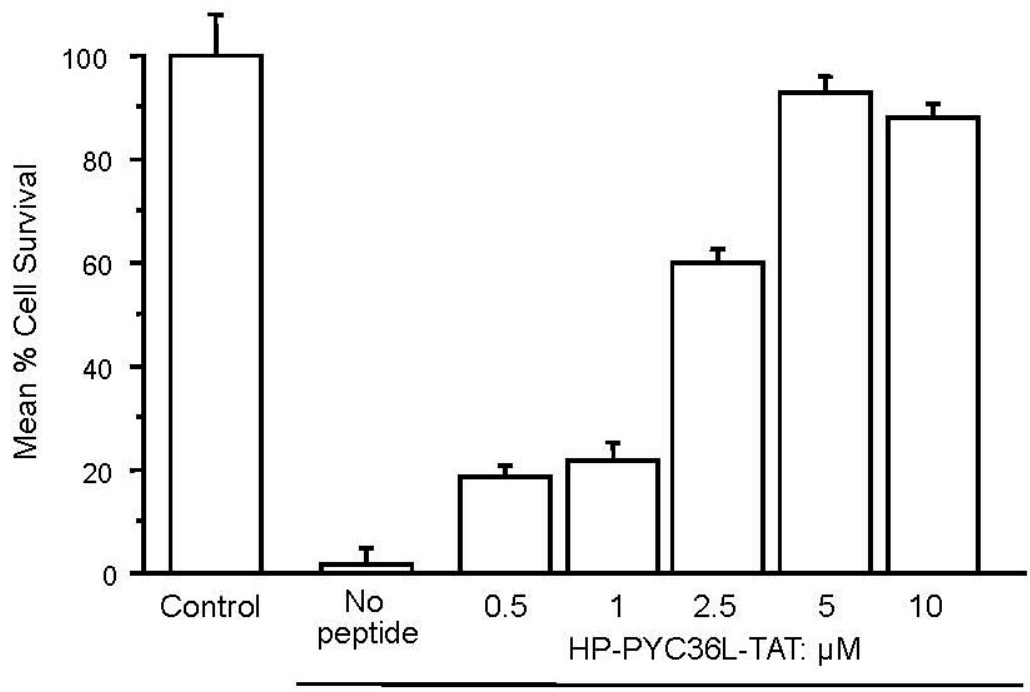

Glutamate: $100 \mu \mathrm{M} / 5 \mathrm{~min}$

Fig 1 - Neuroprotective activity of different concentrations of HP-PYC36L-TAT 24 hours following glutamate exposure $(5 \mathrm{~min} / 100 \mu \mathrm{M})$. MTS data were expressed as percentage neuronal viability with no insult control taken as $100 \%$ viability (mean $\pm S D ; N=4 ;{ }^{*} P<0.05$ ).

\subsection{Treatment protocol and experimental groups}

All treatments or vehicle were randomised and were administered in a blinded manner. In trial 1 , treatments were injected directly into the jugular vein 1 hour post-MCAO, while the animal was still under isoflurane anaesthesia. In trial 2, intravenous administration of treatments was performed 2 hours after MCAO in awake animals using an indwelling cannula primed with heparinized saline inserted into the right jugular vein and externalized through a dorsal mid-scapular incision to a swivel-tether system (Instech Laboratories, Philadelphia, USA) to allow free movement.

For trial 1, treatment groups $(\mathrm{N}=9-13)$ consisted of vehicle $(0.9 \%$ saline), PYC36D-TAT $(500,1000$ or $1500 \mathrm{nmol} / \mathrm{kg}$ ), JNKI-1D-TAT (500, 1000 or 1500 $\mathrm{nmol} / \mathrm{kg})$ and PYC36scrambled-D-TAT peptide (PYC36Dscr-TAT; $1120 \mathrm{nmol} / \mathrm{kg}$ ). The treatment volume dose was $300 \mu \mathrm{l}$. The trial was designed to include 12 animals in each treatment group. However, where there were post-surgical mortalities, exclusions or where availability of the treatment solutions was limiting, some groups ultimately contained fewer animals. Two groups contained 13 animals.
For trial 2, treatment groups $(\mathrm{N}=6)$ consisted of vehicle $(0.9 \%$ saline $)$, D-TAT $(250 \mathrm{nmol} / \mathrm{kg})$, PYC36D-TAT $(50 \mathrm{nmol} / \mathrm{kg}$ or $250 \mathrm{nmol} / \mathrm{kg}$ ), HPPYC36L-TAT (250 nmol/ $\mathrm{kg})$ and JNKI-1D-TAT (250 $\mathrm{nmol} / \mathrm{kg}$ ). The treatment volume dose was $500 \mu \mathrm{l}$. In this trial several animals were excluded due to surgical mortalities, exclusions and in 1 case temperature control equipment failure.

2.6. Tissue processing and infarct volume measurement

Animals were euthanized 24 hours after MCAO via an intraperitoneal injection of sodium pentobarbitone $(900 \mathrm{mg} / \mathrm{kg})$. The brain was removed and placed in a sterile container of $0.9 \% \mathrm{NaCl}$ and then placed in a $80^{\circ} \mathrm{C}$ freezer for 7 minutes. It was then coronally sliced in $2 \mathrm{~mm}$ thickness from the junction of the cerebellum and cerebrum to $12 \mathrm{~mm}$ rostral to this point. The slices were stained with 2\% 2,3,5 triphenyltetrazolium chloride (Sigma, St Louis, MO, USA) at $37^{\circ} \mathrm{C}$ for 20 minutes and then fixed in $4 \%$ formalin at room temperature for at least $18-24$ hours before infarct volume measurement. The slices were scanned and the images were analysed by an operator blinded to treatment status using Image $3^{\text {rd }}$ edition (NIH, USA). The total infarct volume was calculated by measuring the areas of infarcted tissue 
on both sides of the $2 \mathrm{~mm}$ brain sections and multiplied by half slice thickness (i.e. $1 \mathrm{~mm}$ ). The volume was corrected for cerebral oedema by multiplying with the ratio of the normal to affected hemisphere areas (Campbell et al, 2008).

\subsection{Adhesive removal test}

This test measures sensorimotor function by recording the time taken for an animal to remove pieces of adhesives when placed on its forelimbs (Esneault et al, 2008) and was used in trial 2. The animals had adhesive removal tests performed three times per forelimb just before MCAO surgery and once at 24 hours post-treatment. Animals were habituated for 2 minutes in a clear enclosure and an adhesive tape (CryoBabies, Diversified Biotech, Dedham, MA, USA) was placed on the palmar hairless surface of the forepaw. The time from first detection of adhesive tape to time of removal of the tape was measured and recorded for each forelimb (maximum 180 seconds).

\subsection{Statistical analysis}

A

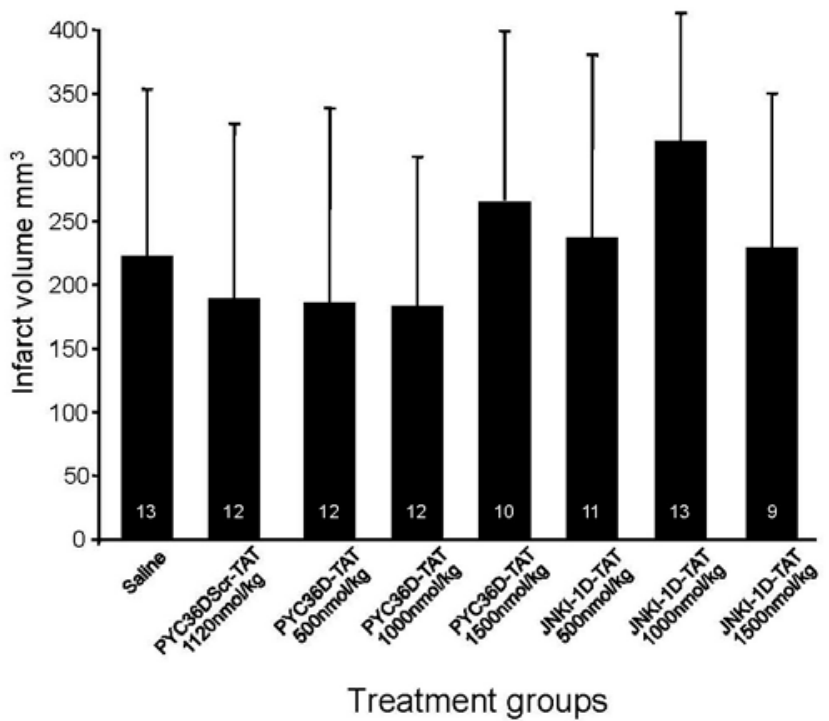

For infarct volume measurements, each treatment group was compared to its respective vehicle control group by analysis of variance (ANOVA) followed by post-hoc Fishers test (StatView). The data obtained are presented as mean \pm standard deviation. ANOVA was employed to compare physiological parameters between groups. For the adhesive tape test, data were analysed using both univariate and multivariate linear regression with the statistical package $\mathrm{R}$ (version 2.11.1). A value of $P<0.05$ was considered significant for all data sets.

\section{Results}

Infarct volume data for trial 1 is presented in Fig. 2 and shows that PYC36D-TAT or JNKI-1D-TAT peptide treatments at any dosage did not significantly reduce ischemic brain injury when compared with PYC36Dscr-TAT and vehicle-treated controls at 24 hours after administration (Fig. 2AB). In this trial we observed across all treatment groups that some animals displayed unusually small infarcts (infarction volume of $<70 \mathrm{~mm}^{3}$ ). Therefore in Figure 2B, we have excluded these animals from the analysis, and still no treatment effects were observed.

\section{B After exclusions}

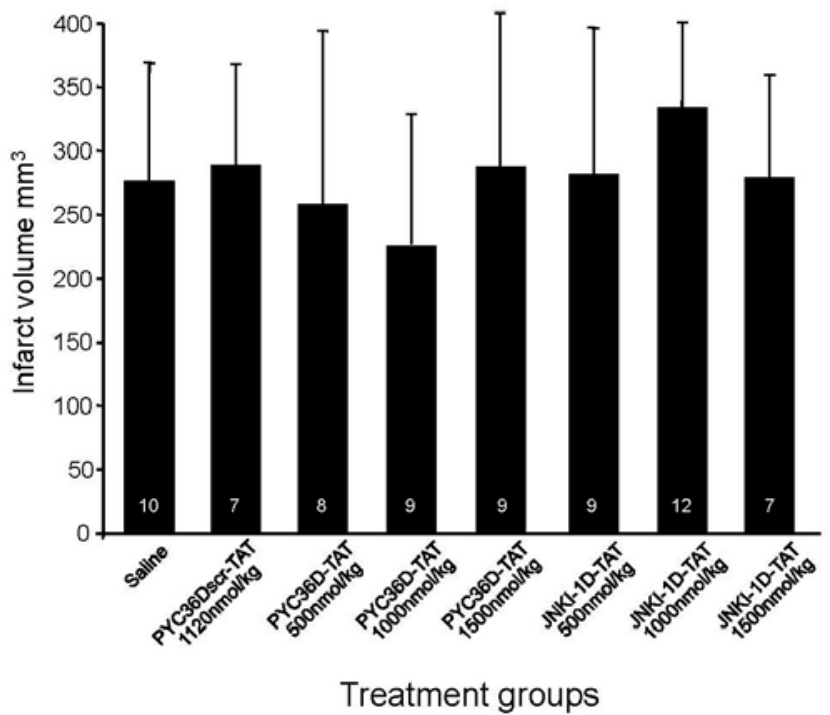

Fig 2 - Effect of different high dose PYC36D-TAT and JNKI-1D-TAT treatment on infarct volume following permanent focal ischemia in Sprague Dawley rats assessed at 24 hours. Peptides were administered 1 hour post-MCAO and no treatment significantly reduced infarct volume. PYC36Dscrambled-TAT (PYC36Dscr-TAT) peptide included as a control. (A) Infarct volume results when all animals are included in trial. (B) Infarct volume results when animals displaying small infarct lesions $\left(<70 \mathrm{~mm}^{3}\right)$ are excluded from the trial. Animal numbers are presented in bars and values are the mean $( \pm \mathrm{SD})$ infarct volumes.

In trial 2, pre-ischemic measurements of blood glucose, blood $\mathrm{pH}$, blood gases $\left(\mathrm{PaCO}_{2}\right.$ and $\left.\mathrm{PaO}_{2}\right)$ and mean arterial blood pressure (MABP) showed no significant differences between the treatment groups (data not shown). Infarct volume measurements are presented in Fig. 3, and show that PYC36D-TAT, 
JNKI-1D-TAT and HP-PYC36L-TAT did not significantly reduce ischemic brain injury when compared with D-TAT and vehicle-treated controls at 24 hours after administration. There were two animals in the vehicle-treated group that displayed small infarcts $\left(<40 \mathrm{~mm}^{3}\right)$, and therefore data with and without the outliers is presented in Fig. 3. The exclusion of these outliers from the data did not demonstrate a statistically significant difference between the vehicle and treatment groups.

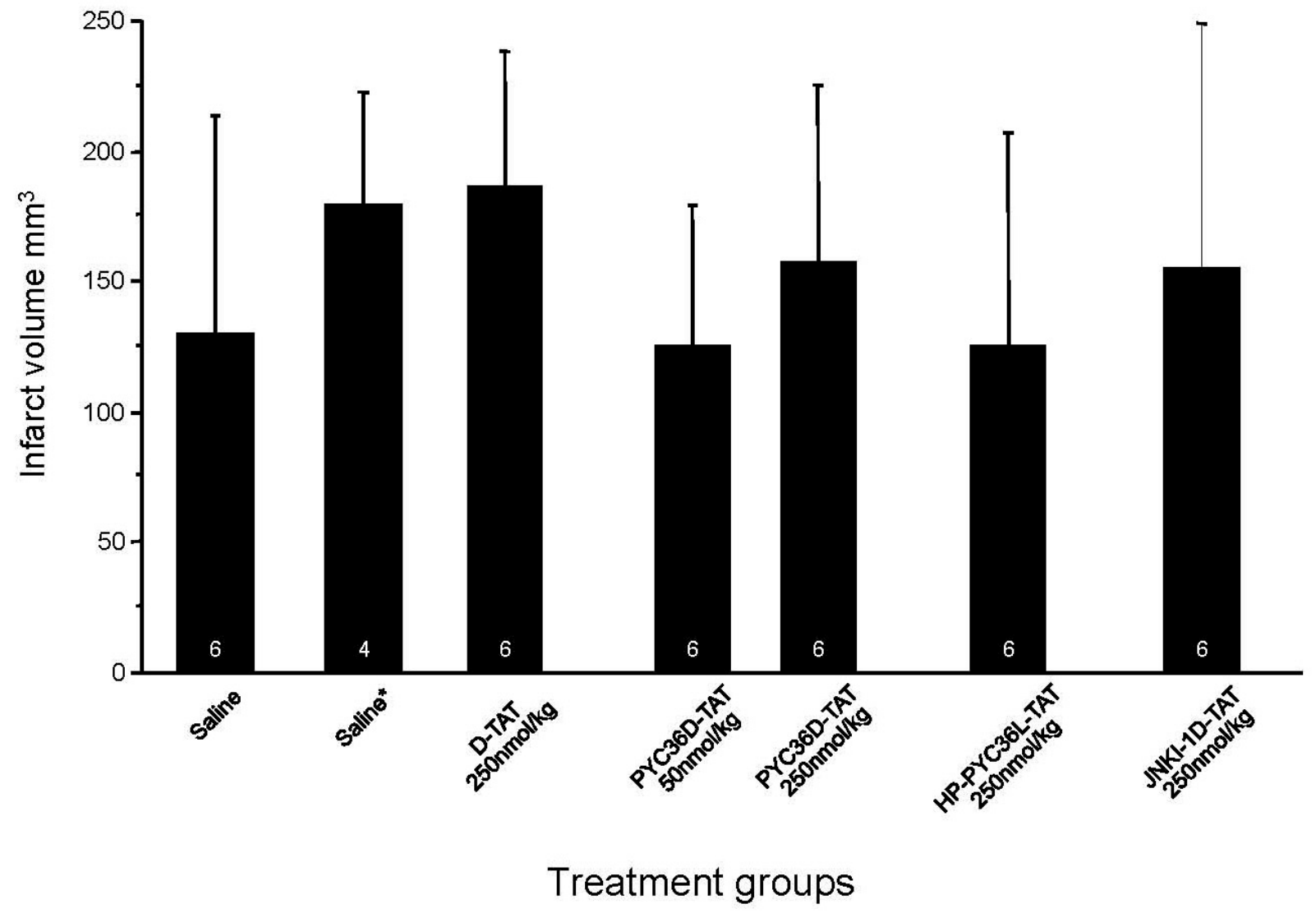

Fig 3. Effect of different low dose PYC36D-TAT and JNKI-1D-TAT treatment on infarct volume following permanent focal ischemia in Sprague Dawley rats assessed at 24 hours. Peptides were administered 2 hours post-MCAO and no treatment significantly reduced infarct volume. Animal numbers are presented in bars and values are the mean $( \pm$ SD) infarct volumes. D-TAT peptide included as a control. *In this saline treatment group animals displaying small infarct lesions $(<$ $40 \mathrm{~mm}^{3}$ ) were excluded.

No significant improvement in functional outcome based on the adhesive removal tests was observed between vehicle and treatment groups (data not shown). All the animals performed poorly in removing the adhesive tapes from the right paw 24 hours postMCAO, with $100 \%$ of them not detecting the tapes on their left paw within the 180-second time limit.

\section{Discussion}

In two trials assessing the ability of two peptides targeting JNK (JNKI-1D-TAT)/C-jun (PYC36D-TAT) signalling to improve stroke outcome in a permanent focal cerebral ischemia rat model, no obvious neuroprotective effects were observed at the tissue or functional level. The negative finding is inline with our previous study assessing the neuroprotective action of the JNKI-1D-TAT and PYC36D-TAT peptides in a rat transient focal cerebral ischemia stroke model (Gow et al, 2011). In the present study, our dose range for JNKI-1D-TAT was $250-1500 \mathrm{nmol} / \mathrm{kg}$ and for PYC36D-TAT 50 - $1500 \mathrm{nmol} / \mathrm{kg}$, which at least for the former peptide is within the range used in previous positive rodent stroke studies. It should also be mentioned, that we have previously reported a lower IC50 value for PYC36D-TAT $(1.3 \mu \mathrm{mol} / \mathrm{L})$ compared to JNKI-1D-TAT (IC50: $2.1 \mu \mathrm{mol} / \mathrm{L}$ ) in glutamate neuronal excitotoxicity model (Meade et al, 2010a). As we reported in our previous negative study (Gow et al, 2011), the lack of any significant neuroprotective with these peptides, especially JNKI1D-TAT, is unexpected given their previously reported in vitro and/or in vivo positive 
neuroprotective effects (Borsello et al, 2003; Hirt et al, 2004; Gao et al, 2005; Repici et al, 2007; Esneault et al, 2008; Soriano et al, 2008; Wiegler et al, 2008; Liu et al, 2010; Benakis et al, 2010; Meade et al, 2010ab; Craig et al, 2011; Vaslin et al, 2011; Table 1).

In the current study, we tried several strategies to obtain a positive outcome. We increased our peptide dosage to 50 - $1500 \mathrm{nmol} / \mathrm{kg}$ from $7.76-255 \mathrm{nmol} / \mathrm{kg}$ as used in our previous study. In order to improve brain delivery due to a more compromised blood brain barrier and to better target the time of $\mathrm{JNK} / \mathrm{c}$ Jun activation, the peptides were administered 2 hours post-MCAO in trial 2, as compared to 1 hour post-occlusion used in trial 1 . In addition, in trial 2 we used a modified PYC36D-TAT peptide (HP-PYC36DTAT: IC50: $1.5 \mu \mathrm{M}$ in glutamate model) fused to a 9 amino acid sequence reported to "home" to ischemic brain tissue (Hong et al, 2008). Finally, we used Sprague Dawley rats, instead of Spontaneously Hypertensive rats used in our first study, as the later strain has an atypical patho-molecular response to glutamate receptor activation (Lecrux et al, 2007), which may have contributed to our previous negative findings. Moreover, other positive JNKI-1D-TAT studies have used Sprague Dawley rats (Esneault et al, 2008; Soriano et al, 200; Liu et al, 2010; Benakis et al, 2010; Vaslin et al, 2011).

Our current and previous negative findings using permanent and transient stroke models in adult rats would suggest that the JNKI-1D-TAT and PYC36DTAT have no or little impact on ischemic brain injury. If this is the case, it raises two important issues. First, what is the likelihood of either of these peptides being effective clinically following stroke, and second, why have most animal stroke studies returned positive outcomes with the JNKI-1D-TAT peptide. With respect to JNKI-1D-TAT, it is of interest that there is only one previously reported positive study using an adult rodent species and a permanent MCAO stroke model (Hirt et al, 2004). The positive permanent stroke model study was performed in mice and peptide delivery was by intracerebral-ventricular injection, with protection observed when treatment was given at 3 hours, but not 6 hours post-MCAO (Hirt et al, 2004). All other positive permanent-type stroke model studies have used 12 or14 day old rats (Soriano et al, 2008; Vaslin et al, 2011), which compared to adult stroke models, animals may experience a milder ischemic insult and/or activate different injury pathways resulting in a protective peptide effect. Interestingly, in the Soriano et al (2008) study, protection with JNKI-1D-TAT was obtained in their standard 14 day old rat permanent MCAO model, but not in their more severe stroke model (pMCAO, plus 90 minute common carotid artery occlusion; CCAO). Similarly, Ginet et al (2009) using a 7-day old rat hypoxia-ischemia model (permanent right CCAO, plus $2 \mathrm{~h} 8 \% \mathrm{O}_{2}$ ) reported that repeated doses of JNKI-1D-TAT did not inhibit brain injury, although calpain and caspase activation was reduced.

Therefore, based on the current experimental data it is likely that stroke model/ischemic severity and timing of peptide administration are important factors, which influence the ability of the JNKI-1D-TAT and PYC36D-TAT peptides to display neuroprotective effects. For example, better success with JNKI-1TAT has been obtained in transient and/or mild permanent MCAO models, using younger animals and when the peptide is administered post-ischemia (Borsello et al, 2003; Wiegler et al, 2008; Benakis et al, 2010; Liu et, 2010; Soriano et al, 2008; Vaslin et al, 2011; Table 1). However, the inconsistent findings using Sprague Dawley rats in a 90 minute MCAO model when JNKI-1D-TAT was administered postischemia (Esneault et al, 2008) and contrasting findings with the peptide in 7 day old rat hypoxiaischemia models (Ginet et al, 2009; Nijboer et al, 2010) is curious. Also of interest, is a recent finding highlighting the neuroprotective effects of prolonged exposure to isoflurane in a neonatal hypoxia-ischemia model (Chen et al, 2011), which was the anesthetic used in over $50 \%$ of the JNK inhibitory peptides studies.

Taken together, it would appear that the experimental stroke data for JNKI-1D-TAT and PYC36D-TAT peptides, do not meet important STAIR guidelines (STAIR, 1999), namely the lack of efficacy when tested in different animal models and/or in different laboratories. Consequently, unless improved treatment regimens (eg. continues 24 hour poststroke infusion) and/or more defined brain ischemia settings (eg. after reperfusion, neonatal hypoxiaischemia) are identified in which these peptides are consistently effective, any further translation to clinical stroke trials should not proceed. 
Table 1: Summary of JNK inhibitory peptide (JNKI-1D/L-TAT) studies in different experimental cerebral ischemia models

\begin{tabular}{|c|c|c|c|c|c|}
\hline Study & $\begin{array}{l}\text { Species } \\
\text { model }^{1}\end{array}$ and & Route and Dose ${ }^{2}$ & Dose timing & End-point & Neuroprotection $^{3}$ \\
\hline $\begin{array}{l}\text { Borsello et al, } \\
2003\end{array}$ & $\begin{array}{l}\text { Mouse: tFCl; } \\
60 \mathrm{~min} / \mathrm{MCAO} \\
\text { Rat }(\mathrm{W}): 14 \text { day } \\
\text { old: } \mathrm{pFCl} / \mathrm{pMCAO}\end{array}$ & $\begin{array}{l}\text { ICV: } 375 \mathrm{nmol} \text { in } 2 \mu \mathrm{l} \\
(16 \mathrm{ng}) \\
\text { IP: } 2800 \mathrm{nmol} / \mathrm{kg}\end{array}$ & $\begin{array}{l}\text { 1h before or } 3,6 \text { or } 12 \mathrm{~h} \\
\text { after MCAO } \\
6 \mathrm{~h} \text { after MCAO } \\
\text { 30min before or } 6 \text { or } 12 \mathrm{~h} \\
\text { after MCAO } \\
6 \mathrm{~h} \text { after MCAO }\end{array}$ & $\begin{array}{l}2 d \\
14 d \\
1 d \\
7 d\end{array}$ & $\begin{array}{l}\text { Yes: } 1 \mathrm{~h} \text { before \& } 3 \text { or } 6 \mathrm{~h} \\
\text { after MCAO; No: } 12 \mathrm{~h} \text { (NS } \\
\text { reduction) } \\
\text { Yes } \\
\text { Yes: all time points } \\
\text { Yes }\end{array}$ \\
\hline $\begin{array}{l}\text { Hirt et al, } \\
2004\end{array}$ & $\begin{array}{l}\text { Mouse: } \\
\mathrm{pFCl} / \mathrm{pMCAO}\end{array}$ & $\begin{array}{l}\text { ICV: 40nmol in } 2 \mu \mathrm{l} \\
(0.15 \mu \mathrm{g})\end{array}$ & 3 or $6 \mathrm{~h}$ after MCAO & $1 d$ & Yes: 3h; No: $6 \mathrm{~h}$ \\
\hline $\begin{array}{l}\text { Gao et al, } \\
2005\end{array}$ & $\begin{array}{l}\text { Mouse: } \text { tFCl; }^{\text {60min/MCAO }}\end{array}$ & ICV: $3 \mu \mathrm{g}$ in $5 \mu \mathrm{l}$ & $\begin{array}{l}\text { 15min before or } 30 \mathrm{~min} \\
\text { after MCAO }\end{array}$ & $2 d$ & Yes: both time points \\
\hline $\begin{array}{l}\text { Guan et al, } \\
2006\end{array}$ & $\begin{array}{lrl}\text { Rat (SD): } & \text { tGCl: } \\
\text { 15min/4VO }\end{array}$ & ICV: $100 \mu \mathrm{g}$ in $10 \mu \mathrm{l}$ & $\begin{array}{l}\text { 40min before or } 60 \mathrm{~min} \\
\text { after } 4 \mathrm{VO}\end{array}$ & $5 d$ & Yes: both time points \\
\hline $\begin{array}{l}\text { Repici et al, } \\
2007\end{array}$ & $\begin{array}{l}\text { Rat }(\mathrm{W}) 14 \text { day } \\
\text { old: } \mathrm{pFCl} \text {; pMCAO } \\
\text { + 90min/CCAO }\end{array}$ & IP: 2800nmol/kg & 30 min before $\mathrm{MCAO}$ & $1 \mathrm{~d}$ & Yes \\
\hline $\begin{array}{l}\text { Esneault et } \\
\text { al, 2008 }\end{array}$ & $\begin{array}{l}\text { Rat (SD): tFCl; } \\
\text { 90min/MCAO }\end{array}$ & $\begin{array}{l}\text { 1) IV: } 7.5,25 \text { or } 75 \\
\mathrm{nmol} / \mathrm{kg} \\
\text { 2) IV: } 25 \mathrm{nmol} / \mathrm{kg} \\
\text { 3) IV: } 25 \mathrm{nmol} / \mathrm{kg}\end{array}$ & 3h after MCAO & $\begin{array}{l}3 d \\
6 d \\
10 d\end{array}$ & $\begin{array}{l}\text { Yes: } 25 \mathrm{nmol} / \mathrm{kg} \text { dose; No: } \\
7.5 \& 75 \mathrm{nmol} / \mathrm{kg} \text { dose (NS } \\
\text { reduction) } \\
\text { No: (NS reduction) } \\
\text { No }\end{array}$ \\
\hline $\begin{array}{l}\text { Soriano et al, } \\
2008\end{array}$ & $\begin{array}{l}\text { Rat (SD) } 12 \text { day } \\
\text { old: } \\
\text { 1) } \mathrm{pFCl} / \mathrm{pMCAO} \\
\text { 2) pMCAO + } \\
\text { 90min/CCAO }\end{array}$ & IP: $75 \mathrm{nmol} / \mathrm{kg}$ & $\begin{array}{l}\text { 6h after MCAO } \\
30 \mathrm{~min} \text { before or } 6 \mathrm{~h} \text { after } \\
\text { MCAO }\end{array}$ & $1 d$ & Yes \\
\hline $\begin{array}{l}\text { Wiegler et al, } \\
2008\end{array}$ & $\begin{array}{l}\text { Mouse: } \mathrm{tFCl} \\
\text { 30min/MCAO }\end{array}$ & $\begin{array}{l}\text { IV: } 0.076, \quad 0.76, \quad 7.6 \text {, } \\
76,255 \text { or } 760 \mathrm{nmol} / \mathrm{kg}\end{array}$ & $6 \mathrm{~h}$ post after MCAO & $2 d$ & Yes: all doses \\
\hline $\begin{array}{l}\text { Ginet et al, } \\
2009\end{array}$ & $\begin{array}{l}\text { Rat (SD) } 7 \text { day } \\
\text { old: } \mathrm{HI}: \text { pCCAO + } \\
8 \% \mathrm{O}_{2} / 2 \mathrm{~h}\end{array}$ & IP: $75 \mathrm{nmol} / \mathrm{kg}$ & $\begin{array}{l}30 \mathrm{~min} \text { before } \& 3,5,8,12 \\
\& 20 \mathrm{~h} \text { after CCAO }\end{array}$ & $1 \& 7 d$ & No \\
\hline $\begin{array}{l}\text { Liu et al, } \\
2010\end{array}$ & $\begin{array}{l}\text { Rat (SD): tFCl } \\
\text { 1) } 30 \mathrm{~min} / \mathrm{MCAO} \\
\text { 2) } 90 \mathrm{~min} / \mathrm{MCAO}\end{array}$ & $\begin{array}{l}\text { 1) IP: } 5100 \mathrm{nmol} / \mathrm{kg} \\
\text { 2) IP: } 125 \text { or } \\
\text { 510nmol } / \mathrm{kg} \\
\text { IP: } 510 \mathrm{nmol} / \mathrm{kg}\end{array}$ & $\begin{array}{l}\text { 30min before MCAO } \\
\text { 3h after MCAO } \\
\text { 3h after MCAO }\end{array}$ & $\begin{array}{l}1 d \\
1 d\end{array}$ & 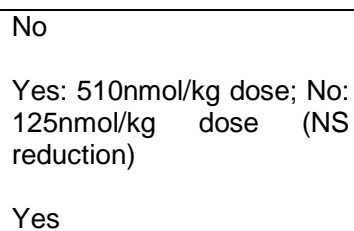 \\
\hline $\begin{array}{l}\text { Benakis et al, } \\
2010\end{array}$ & $\begin{array}{l}\text { Mouse: } \\
\text { 45min/MCAO }\end{array}$ & IV: $25 \mathrm{nmol} / \mathrm{kg}$ & 3h after MCAO & $2 d$ & Yes \\
\hline $\begin{array}{l}\text { Nijboer et al, } \\
2010\end{array}$ & $\begin{array}{l}\text { Rat (W) } 7 \text { day old: } \\
\mathrm{HI}: \text { pCCAO + } 8 \% \\
\mathrm{O}_{2} / 2 \mathrm{~h}\end{array}$ & IP: 2550nmol/kg & $\begin{array}{l}\text { Omin } \& 3 \mathrm{~h} \text { after or } 3 \text { or } 6 \mathrm{~h} \\
\text { after } \mathrm{HI}\end{array}$ & $2 d$ & $\begin{array}{l}\text { Yes: } 0 \text { min } \& 3 \mathrm{~h} \text { after or } 3 \mathrm{~h} \\
\text { after } \mathrm{Hl} \text {; No: } 6 \mathrm{~h}\end{array}$ \\
\hline $\begin{array}{l}\text { Vaslin et al, } \\
2011\end{array}$ & $\begin{array}{l}\text { Rat: (SD) } 12 \text { day } \\
\text { old: } \mathrm{pFCl} / \mathrm{MCAO}\end{array}$ & 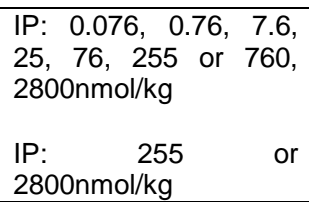 & $\begin{array}{l}\text { 6h after MCAO } \\
\text { 4h before MCAO }\end{array}$ & $1 d$ & $\begin{array}{l}\text { Yes: } 7.6, \quad 25, \quad 76 \quad \& \\
2800 \mathrm{nmol} / \mathrm{kg} \text { doses; NS } \\
\text { reduction for other doses } \\
\text { No }\end{array}$ \\
\hline $\begin{array}{lll}\text { Gow } & \text { et al, } \\
2011 & & \\
\end{array}$ & $\begin{array}{l}\text { Rat (SH): tFCl; } \\
\text { 90min/MCAO }\end{array}$ & IV: $255 \mathrm{nmol} / \mathrm{kg}$ & 2.5 or $3.5 \mathrm{~h}$ after MCAO & $2 d$ & No \\
\hline $\begin{array}{l}\text { Si et al, } \\
\text { current study }\end{array}$ & $\begin{array}{l}\text { Rat (SD): } \mathrm{pFCl} ; \\
\text { pMCAO }\end{array}$ & $\begin{array}{l}\text { 1) IV: 500, 1000, } \\
\text { 1500nmol/kg } \\
\text { 2) IV: } 250 \mathrm{nmol} / \mathrm{kg}\end{array}$ & $\begin{array}{l}\text { 1h after MCAO } \\
\text { 2h after MCAO } \\
\end{array}$ & $\begin{array}{l}1 \mathrm{~d} \\
1 \mathrm{~d} \\
\end{array}$ & $\begin{array}{l}\text { No } \\
\text { No }\end{array}$ \\
\hline
\end{tabular}




\section{Acknowledgements}

This study was supported by the Neuromuscular Foundation of Western Australia and by a grant from the National Heart Foundation (Australia). The authors would like to acknowledge Joanne Chieng and Vince Clark for technical assistance.

\section{Conflict of Interest}

Paul Watt is an Executive Director for Phylogica Ltd Pty. Nadia Milech is a Senior Scientist working for Phylogica. Bruno Meloni is a Phylogica shareholder. The other authors declare no conflict of interest.

\section{References}

Benakis C, Bonny C, Hirt L. JNK inhibition and inflammation after cerebral ischemia. Brain Behav Immun. 2010;24:800-11.

Besirli CG, Wagner EF, Johnson EM Jr. The limited role of $\mathrm{NH} 2$-terminal c-Jun phosphorylation in neuronal apoptosis: identification of the nuclear pore complex as a potential target of the JNK pathway. J Cell Biol. 2005;170:401-11.

Borsello T, Clarke PG, Hirt L, Vercelli A, Repici M, Schorderet DF, Bogousslavsky J, Bonny C. A peptide inhibitor of $\mathrm{c}$-Jun $\mathrm{N}$-terminal kinase protects against excitotoxicity and cerebral ischemia. Nat Med. 2003;9:1180-6.

Campbell K, Meloni BP, Knuckey NW. Combined magnesium and mild hypothermia $\left(35^{\circ} \mathrm{C}\right)$ treatment reduces infarct volumes after permanent middle cerebral artery occlusion in the rat at 2 and 4 , but not 6h. Brain Res. 2008;1230:258-64.

Cao G, Pei W, Ge H, Liang Q, Luo Y, Sharp FR, Lu A, Ran $\mathrm{R}$, Graham $\mathrm{SH}$, Chen J. In vivo delivery of a $\mathrm{Bcl}-\mathrm{xL}$ fusion protein containing the TAT protein transduction domain protects against ischemic brain injury and neuronal apoptosis. J Nuerosci. 2002;22:5423-31.

Chen H, Burris M, Fajilan A, Spagnoli F, Tang J, Zhang JH. Prolonged exposure to isoflurane ameliorates infarction severity in the rat pup model of neonatal hypoxiaischemia. Transl Stroke Res. 2011;2:382-90.

Craig AJ, Meloni BP, Watt PM, Knuckey NW. Attenuation of neuronal death by peptide inhibitors of AP-1 activation in acute and delayed in vitro ischemia (oxygen/glucose deprivation) models. Int J Pept Res Ther. 2011;17:1-6.

Donnan GA, Davis SM. Stroke drug development: usually, but not always, animal models. Stroke. 2005;36:2326.

Esneault E, Castagne V, Moser P, Bonny C, Bernaudin M. $\mathrm{D}$-JNKi, a peptide inhibitor of $\mathrm{C}$-Jun $\mathrm{N}$-terminal kinase, promotes functional recovery after transient focal cerebral ischemia in rats. Neuroscience. 2008;152:308-20.

Gao Y, Signore AP, Yin W, Cao G, Yin XM, Sun F, Luo Y, Graham SH, Chen J. Neuroprotection against focal ischemic brain injury by inhibition of $\mathrm{C}$-Jun $\mathrm{N}$-terminal kinase and attenuation of the mitochondrial apoptosissignaling pathway. J Cereb Blood Flow Metab. 2005;25:694-712.

Ginet V, Puyal J, Magnin G, Clarke PG, Truttmann AC. Limited role of the C-Jun N-terminal kinase pathway in a neonatal rat model of cerebral hypoxia-ischemia. $\mathrm{J}$ Neurochem. 2009;108:552-62.

Gow WR, Campbell K, Meade AJ, Watt P, Milech, N, Knuckey NW, Meloni BP. Lack of neuroprotection of inhibitory peptides targeting Jun/JNK following transient focal cerebral ischemia in Spontaneously Hypertensive rats. J Cereb Blood Flow Metab. 2011;31:e1-e8.

Guan QH, Pei DS, Zong YY, Xu TL, Zhang GY. Neuroprotection against ischemic brain injury by a small peptide inhibitor of c-Jun $\mathrm{N}$-terminal kinase (JNK) via nuclear and non-nuclear pathways. Neuroscience. 2006;139:609-27.

Hirt L, Badaut J, Thevenet J, Granziera C, Regli L, Maurer F, Bonny C, Bogousslavsky J. D-JNKI1, a cellpenetrating c-Jun-N-terminal kinase inhibitor, protects against cell death in severe cerebral ischemia. Stroke. 2004;35:1738-43.

Hong HY, Choi JS, Kim YJ, Lee HY, Kwak W, Yoo J, Lee JT, Kwon TH, Kim IS, Han HS, Lee BH. Detection of apoptosis in a rat model of focal cerebral ischemia using a homing peptide selected from in vivo phage display. J Control Release. 2008;131:167-72.

Lecrux C, Nicole O, Chazalviel L, Catone C, Chuquet J, MacKenzie ET, Touzani O. Spontaneously Hypertensive Rats are highly vulnerable to AMPAinduced brain lesions. Stroke. 2007;38:3007-15.

Liu J-R, Zhao Y, Patzer A, Staak N, Boehm G, Culman J, Bonny $\mathrm{C}$, Herdegen $\mathrm{T}$, Eschenfelder $\mathrm{C}$. The $\mathrm{C}$-Jun $\mathrm{N}$ terminal kinase (JNK) inhibitor XG-102 enhances the neuroprotection of hyperbaric oxygen after cerebral ischemia in adult rats. Neuropathol Appl Neurobiol. 2010;36:211-24.

Meade AJ, Meloni BP, Cross J, Bakker AJ, Fear MW, Mastaglia FL, Watt PM, Knuckey NW. AP-1 inhibitory peptides are neuroprotective following acute glutamate excitotoxicity in primary cortical neuronal cultures. J Neurochem. 2010a;112:258-70.

Meade AJ, Meloni BP, Mastaglia FL, Watt PM, Knuckey NW. AP-1 inhibitory peptides attenuate in vitro cortical neuronal cell death induced by kainic acid. Brain Res. 2010b;1360:8-16.

Nijboer $\mathrm{CH}$, van der Kooij MA, van Bel F, Ohl F, Heijnen CJ, Kavelaars A. Inhibition of the JNK/AP-1 pathway reduces neuronal death and improves behavioral outcome after neonatal hypoxic-ischemic brain injury. Brain Behav Immun. 2010;24:812-21. 
Plesnila N, Zinkel S, Le DA, Amin-Hanjani S, Wu Y, Qiu J, Chiarugi A, Thomas SS, Kohane DS, Korsmeyer SJ, Moskowitz MA. BID mediates neuronal cell death after oxygen/glucose deprivation and focal cerebral ischemia. Proc Natl Acad Sci USA. 2001;98:15318-23.

Repici M, Centeno C, Tomasi S, Forloni G, Bonny C, Vercelli A, Borsello T. Time-course of C-Jun N-terminal kinase activation after cerebral ischemia and effect of D-JNKI1 on C-Jun and caspase-3 activation. Neuroscience. 2007;150:40-9.

Soriano FX, Martel MA, Papadia S, Vaslin A, Baxter P, Rickman C, Forder J, Tymianski M, Duncan R, Aarts M, Clarke P, Wyllie DJ, Hardingham GE. Specific targeting of pro-death NMDA receptor signals with differing reliance on the NR2B PDZ ligand. J Neurosci. 2008;28:10696-710.

STAIR. Recommendations for standards regarding preclinical neuroprotective and restorative drug development. Stroke. 1999;30:2752-8.

Tsuruta F, Sunayama J, Mori Y, Hattori S, Shimizu S, Tsujimoto Y, Yoshioka K, Masuyama N, Gotoh Y. JNK promotes Bax translocation to mitochondria through phosphorylation of 14-3-3 proteins. EMBO J. 2004;23:1889-99.

Vaslin A, Naegele-Tollardo S, Puyal J, Clarke PG. Excitotoxicity-induced endocytosis mediates neuroprotection by TAT-peptide-linked JNK inhibitor. J Neurochem. 2011;119:1243-52.

Wang XT, Pei DS, Xu J, Guan QH, Sun YF, Liu XM, Zhang GY. Opposing effects of Bad phosphorylation at two distinct sites by Akt1 and JNK1/2 on ischemic brain injury. Cell Signal. 2007;9:1844-56.

Wiegler K, Bonny C, Coquoz D, Hirt L. The JNK inhibitor XG-102 protects from ischemic damage with delayed intravenous administration also in the presence of recombinant tissue plasminogen activator. Cerebrovasc Dis. 2008;26:360-6.

Zhu H, Meloni BP, Bojarski C, Knuckey MW, Knuckey NW. Post-ischemic modest hypothermia $\left(35^{\circ} \mathrm{C}\right)$ combined with intravenous magnesium is more effective at reducing CA1 neuronal death than either treatment used alone following global cerebral ischemia in rats. Exp Neurol. 2005;193:361-8. 